7. Petřková, A. Gerontagogika. Úvod do teorie a praxe edukace seniorů [Text] / A. Petřková, R. Čornaničová. Olomouc: Univerzita Palackého, 2004. - 92 s.

8. Mühlpachr, P. Geragogika pro speciální pedagogy [Text] / P. Mühlpachr, P. Staníček. - Brno: Masarykova univerzita, 2001. - $116 \mathrm{~s}$.

9. Hrapková, N. The personality of the teacher education seniors [Text]: proc. of conf. / N. Hrapková // University of the Third Age. Past, Present and prospects for further development. Brno: Masarykova univerzita (Czech Republic), 2010. - S. 91-100.

10. Kryštof, D. Key competencies senior lecturer in education [Text]: proc. of conf. / D. Kryštof, N. Špatenková // University of the Third Age. Past, Present and prospects for further development. - Brno: Masarykova univerzita (Czech Republic), 2010. - S. 115-125.

\section{References}

1. Husén, T. (1967). Metodika vzdělávání dospělých [Methodology of adult education]. Praha: Socialistická akademie, 66.2. Petřková, A., Bočková, V. (1994). Education of seniors as the current issue of adult education. Proceding of Conference. Current problems of adult education. Olomouc: Univerzita Palackého (Czech Republic), 50.
3. Mühlpachr, P. (2004). Gerontopedagogika [Gerontopedagogy]. Brno: Masarykova univerzita, 204.

4. Benešová, D. (2014). Gerontagogika [Gerontagogy]. Praha: UJAK, 136.

5. The Ministry of Labour and Social Affairs in Prague. Available at: http://www.mpsv.cz/cs/5045

6. Průcha, J., Veteška, J. (2012). Andragogický slovník [Andragogical dictionary]. Praha: Grada, 294.

7. Petřková, A., Čornaničová, R. (2004). Gerontagogika. Úvod do teorie a praxe edukace seniorů [Gerontagogy. Introduction to the theory and practice of education of seniors]. Olomouc, Czech Republic: Univerzita Palackého, 92.

8. Mühlpachr, P., Staníček, P. (2001). Geragogika pro speciální pedagogy [Geragogy for special educators]. Brno: Masarykova univerzita, 116.

9. Hrapková, N. (2010). The personality of the teacher education seniors. Proceding of Conferenc. University of the Third Age. Past, Present and prospects for further development. Brno: Masarykova univerzita (Czech Republic), 91-100.

10. Kryštof, D., Špatenková, N. (2010). Key competencies senior lecturer in education. Proceding of Conference. Past, Present and prospects for further development. Brno: Masarykova univerzita (Czech Republic), 115-125.

Дата надходження рукопису 21.09.2016

Mgr. Petra Kaduchová, Second year of Doctor's Degree of Education Program, Department of Education and Social Studies, Palacky University Olomouc, Žižkovo náměstí 5, 77140 Olomouc, Czech Republic E-mail: kaduchova@epol.cz

\title{
УДК 37.013.78
}

\section{ДОСЛІДЖЕННЯ КРИТЕРІЇВ ТА ПОКАЗНИКІВ РОЗВИТКУ ЗАГАЛЬНОЇ СЕРЕДНЬОЇ ОСВІТИ В УКРАЇНI}

\section{(C) І. О. Климчук}

В статті подається аналіз вітчизняних $і$ зарубіжних показників стану загальної середньої освіти в Україні, зокрема: показників розвитку освіти, показників загальних витрат на освіту, показників структури видатків у державних закладах освіти в Україні та в країнах Західної Свропи, показників річної заробітної платні вчителів в Украӥні та в країнах Західної Європи. 3 метою вдосконалення системи показників/критеріїв оцінювання рівня освіти в Украӥні визначені основні напрями удосконалення системи розвитку загальної середньої освіти

Ключові слова: загальна середня освіта, статистичні показники розвитку освіти, міжнародні показники/індикатори розвитку освіти

Under the modern conditions of Ukrainian economic development the one of the most acute problems of education is not only the lack of state financing but also the ineffectiveness of the costs usage by educational institutions that makes impossible their further development, obtaining the certain level in the international rating of educational standards. The insufficient level of elaboration of the effective use of state management and financing of educational institutions needs the further scientific searches, aimed at the improvement of the system of indicators and criteria of assessment of Ukrainian education from preschool to the higher one.

The main statistical indices of the Ukrainian education development for the period 2008-2016, the indices of general costs on education in Ukraine comparing with other countries of Western Europe (2008-2012), the indices of costs on one pupil in Ukraine and in the countries of Western Europe (2007-2014), indices of costs structure in educational institutions (2007-2014), indices of the state costs on the different levels of education in Ukraine and countries of Western Europe, indices of annual salary of the teachers in Ukraine and countries of Western Europe (2014) were presented in the article. The analysis of existing state of education development and the sources of formation of financial resources of educational institutions was carried out, the priority directions of the development system of GSE, according to the author, were defined

Keywords: general secondary education in Ukraine, statistical indices of education development, international parameters/indices of education development 


\section{1. Вступ}

На сьогодні зміни в ураїнському суспільстві зумовлюють необхідні зміни в освіті, життя потребує поточного регулювання динаміки розвитку освіти, розробки відповідних критеріїв та показників прогнозування та розвитку освіти. В якості беззаперечного прикладу було запровадження в Україні зовнішнього незалежного оцінювання (ЗНО), що підвищило інтерес до внутрішньошкільного оцінювання, уможливило використання результатів оцінювання як основного показника ефективності роботи школи та якості навчально-виховного процесу. Однак, результати зовнішнього незалежного оцінювання хоч і слугують важливою інформацією для аналізу якості освіти зокрема, проте їх недостатньо для того, щоб мати об’єктивноцілісну картину оцінюваня рівня розвитку всієї загальної середньої освіти. Потрібна система не розрізнених вимірів - вивчення стану викладання предметів, вивчення досвіду роботи педагогів, атестація педагогічних працівників тощо, що проводяться районними чи обласними відділами (управліннями) освіти. Хоч вони і проводяться у системі, але є епізодичними. Практично ці виміри відображені в атестації загальноосвітнього навчального закладу (відбувається на один раз у десять років і триває не більше п'ятнадцяти днів), атестації вчителя (відбувається традиційно один раз на п'ять років), атестації робочого місця (кабінетів), вивченні стану викладання навчальних предметів, зовнішньому незалежному оцінюванні, державній підсумковій атестації тощо. Та постають питання: «На скільки ці процедури здатні ефективно впливати на якість загальної (базової) освіти?», «На скільки вони дієві?», «Чи можуть вони показати весь позитив, або, навпаки, виявити негатив, недосконалість у роботі навчального закладу?»«Чи можуть вони оперативно вплинути на зміни, що відбуваються в суспільстві?» Існуючи показники/критерії не є тими ефективними інструментами, що дають повну картину стану освіти в країні. 3 метою з'ясування питань щодо відповідності якості освіти державним та міжнародним стандартам, а також здійсненню за їх допомогою прогнозування розвитку загальної освіти був проведений аналіз сучасного стану освіти в Україні.

\section{2. Аналіз літературних джерел}

Сучасні зарубіжні та вітчизняні науковці активно та всесторонньо займаються вивченням питань моніторингу, прогнозування розвитку та якості освіти, здійснюють аналіз питань проблем вимірювання рівнів знань учнів, перевірки якісного складу педагогічного колективу, реформування управлінського аспекту роботи ЗНЗ тощо [1-6].

В педагогічній науці проблемі вимірювання, розробці питань моніторингу та оцінці якості освіти, проблемам вимірювання результативності педпрацівників та учнів, оцінці ділових, професійних і особистісних якостей педагогічного персоналу, моніторингу діяльності учнів та вчителів, питанням вимірювання результативності учнів і педагогів, моніторингу організаційно-педагогічної діяльності керівника та заступника керівника школи приділяляється чимало уваги і наукових доробок [2-9].
Досліджуються проблеми управління школою, розроблено технологію оцінювання управлінської діяльності керівників ЗНЗ, розроблені критерії та параметри оцінювання єфективності уроків тощо. В соціально-педагогічному аспекті проблемам ефективності управління загальноосвітньою школою та проблемам поліпшення державного управління та підвищення якості освіти на національному та регіональному рівнях досліджуються багатьма вітчизняними та зарубіжними науковцями $[4,5,8,10]$.

Міжнародні критерії оцінювання якості освіти теж представлені відповідними показниками (індикаторами). Найпоширенішими серед них є - освітні показники/індикатори Ради з освіти Європейського Союзу, Освітні індикатори Міжнародного Консультативного Форуму з освіти для всіх, Освітні індикатори ЮНЕСКО, ОЕСР. Окремі освітні індикатори входять до системи міжнародної оцінки суспільного розвитку окремих держав, до різних міжнародних моніторингових систем, зокрема індекс людського розвитку (Human Development Index), що використовується у звітах $\mathrm{OOH}$, та індикатори світового розвитку (World Development Indicators), які визначає Світовий банк. Огляд публікацій з проблем визначення основних критеріїв/показників розвитку освіти уможливив зробити висновок, що питання підвищення якості вітчизняної освіти, процедура розробки нових критеріїв/показників оцінки освітньої діяльності неможливі без відповідного аналізу сучасного стану освіти в Україні.

\section{3. Мета та задачі дослідження}

Метою проведеного дослідження було: вивчення стану освіти в Україні, й середньої зокрема; пошук, обробка та аналіз основних статистичних показників розвитку освіти в Україні за період 2008 2016 рр. Відповідно до поставленої мети були визначені завдання дослідження, а саме пошук та аналіз: показників/даних загальних витрат на освіту в Україні в порівнянні з іншими країнами Західної Европи (2008-2012 рр.); показників/даних витрат на одного учня за рік в Україні та країнах Західної Свропи (2007-2014pp.); показників/даних структури видатків у державних закладах освіти в Україні та країнах Західної Європи (2008-2014рр.); показників державних витрат на різні рівні освіти в Україні та країнах Західної Свропи (2008-2014рр.) показників/даних річної заробітної платні вчителів в Україні та країнах Західної Свропи (2014р.). Матерілами для проведення дослідження були: наукові джерела, данні Державної служби статистики (OECD, Eurydice).Для реалізації мети і завдань дослідження використовувався: аналіз наукової та статистичної літератури; збір та аналіз статистичних даних.

4. Порівняльний аналіз основних показників розвитку загальної середньої освіти в Україні та в країнах Західної Європи

Видатки на освіту як частка від ВВП в Україні $\epsilon$ дуже високими, якщо порівнювати з розвинутими країнами світу. Однак слід зважати на значну частку тіньової економіки (обсяг якої, за різними оцінками, може сягати $50 \%$ ), тобто реальний обсяг 
українського ВВП є більшим, ніж офіційно розрахований. Відповідно, реальна частка витрат на освіту може бути меншою. Іншою особливістю фінансування освіти в Україні $\epsilon$ його розпорошеність. Держава фінансує дуже розгалужену мережу навчальних закладів. Попри високий показник видатків на освіту як частки від ВВП видатки на одного учня/студента та заробітну платню вчителям є дуже низькими в порівнянні з іншими країнами. Однак, протягом останніх 12 років видатки на освіту у зведеному бюджеті України складали одну з найбільших статей $-18-21 \%$ (рис. 1).

Як свідчать дані (рис. 2) більшість розвинутих країн світу, за винятком Італії, Ірландії та Португалії, за зазначений період збільшували частку капітальних видатків в освіті. Протягом 2008-2011 років найбільші темпи зростання видатків демонстрували Канада, Чехія, Швеція, Литва та Латвія. Натомість в Україні частка капітальних видатків на освіту була досить низькою (менше лише у Португалії). Відповідно, за період 20132016 рр. витрати на освіту збільшились у 2016 році на 7 \% у порівнянні з 2013 роком (рис. 2) [9].
Починаючи з 2015 року середня освіта в Україні фінансується коштами освітньої субвенції. Вона розподіляється між місцевими бюджетами за формулою, яка базується на нормативі фінансування на одного учня та кількості учнів на відповідній території, враховуючи, тип загальноосвітнього навчального закладу та його місцезнаходження (місто, село, регіон тощо). Слід зазначити, що розвинуті европейські країни розподіляють значно більшу частку витрат на користь середньої та середньої професійної, ане вищої освіти, на відміну від України. В Україні частка витрат відповідно на ці рівні освіти на $14 \%$ менша, ніж у країнах Західної Свропи. Багато в чому це пов'язано з тривалістю шкільної освіти, яка у розвинутих європейських країнах здебільшого складає 12-13 років. Натомість частка витрат на вищу освіту в Україні вища, ніж в середньому по ОЕСР. Найближчими до українських є показники Чилі та США, але на відміну від України, вони мають значну частку недержавного фінансування вищої та середньої професійної освіти у вигляді недержавних (благодійних) фондів (рис. 3).

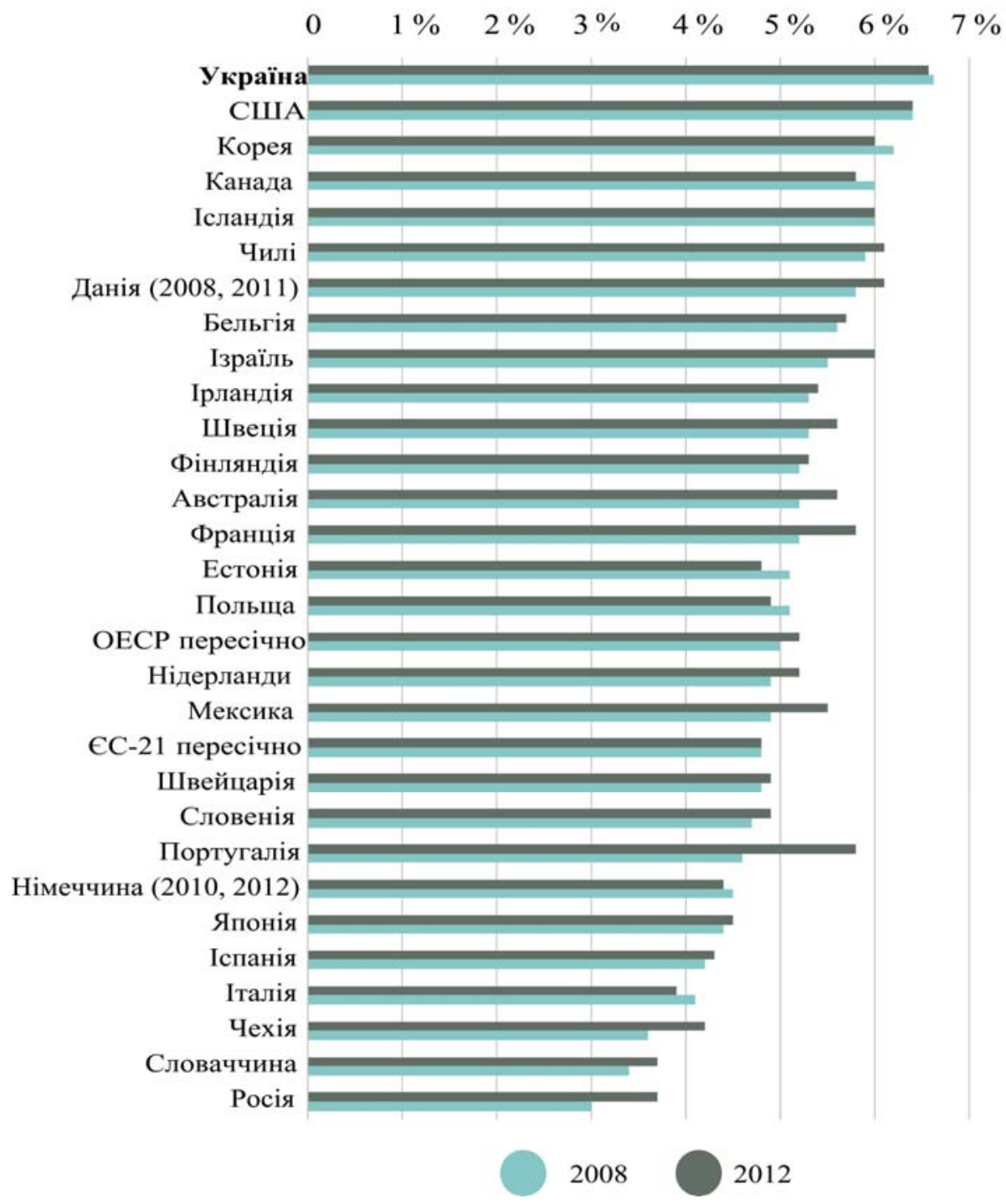

Рис. 1. Загальні витрати на освіту без дошкільної у \% від ВВП в Україні в порівнянні з іншими країнами 2008-2012 р (Джерело: Державна служба статистики, OECD) 
Однак, слід зазначити, що наведені показники не відображають двох основних тенденцій розвитку освіти в Україні. Так, сюди не включені витрати батьків на репетиторство, шкільні/благодійні внески, не враховано також часткове повторення програми середньої школи на «нульових»/підготовчих курсах при ВИШах. Окрім цього, потрібно брати до уваги той факт, що чим бідніша країна, тим більша у бюджеті частка видатків на середню освіту (SianesiandVanReenen, 2002).

У період з 2010 по 2014 рік реальні витрати на одного учня зросли в усіх країнах Західної Свропи. В Украні найвищі темпи росту були у професійнотехнічній (+32\%) та вищій (+30\%) освіті. Зростання зумовлене не стільки збільшенням фінансування, скільки скороченням кількості учнів за цей період через складну політичну та демографічну ситуацію в країні (рис. 4).

Майже усі розвинуті країни попри фінансову кризу 2008-2014 років збільшили річні видатки на одного учня. У початковій школі найбільші темпи зростання у таких країн, як: Чилі, Литва, Словаччина, Польща, Чехія, Німеччина - $з$ показником 32-64 \%. У основній школі - Великобританія, Словаччина, Польща, Чилі, Чехія, Німеччина, Естонія - відповідно на 29-70 \%. У старшій школі зростання було повільнішим, більш високі темпи - показали Чилі, Польща, Словаччина, Словенія, Естонія, Фінляндія - відповіднона 26-44%. Як свідчать наведені дані, в Україні найменші витрати на одного учня серед усіх країн Західної Європи. Найменші - тільки у Румунії.

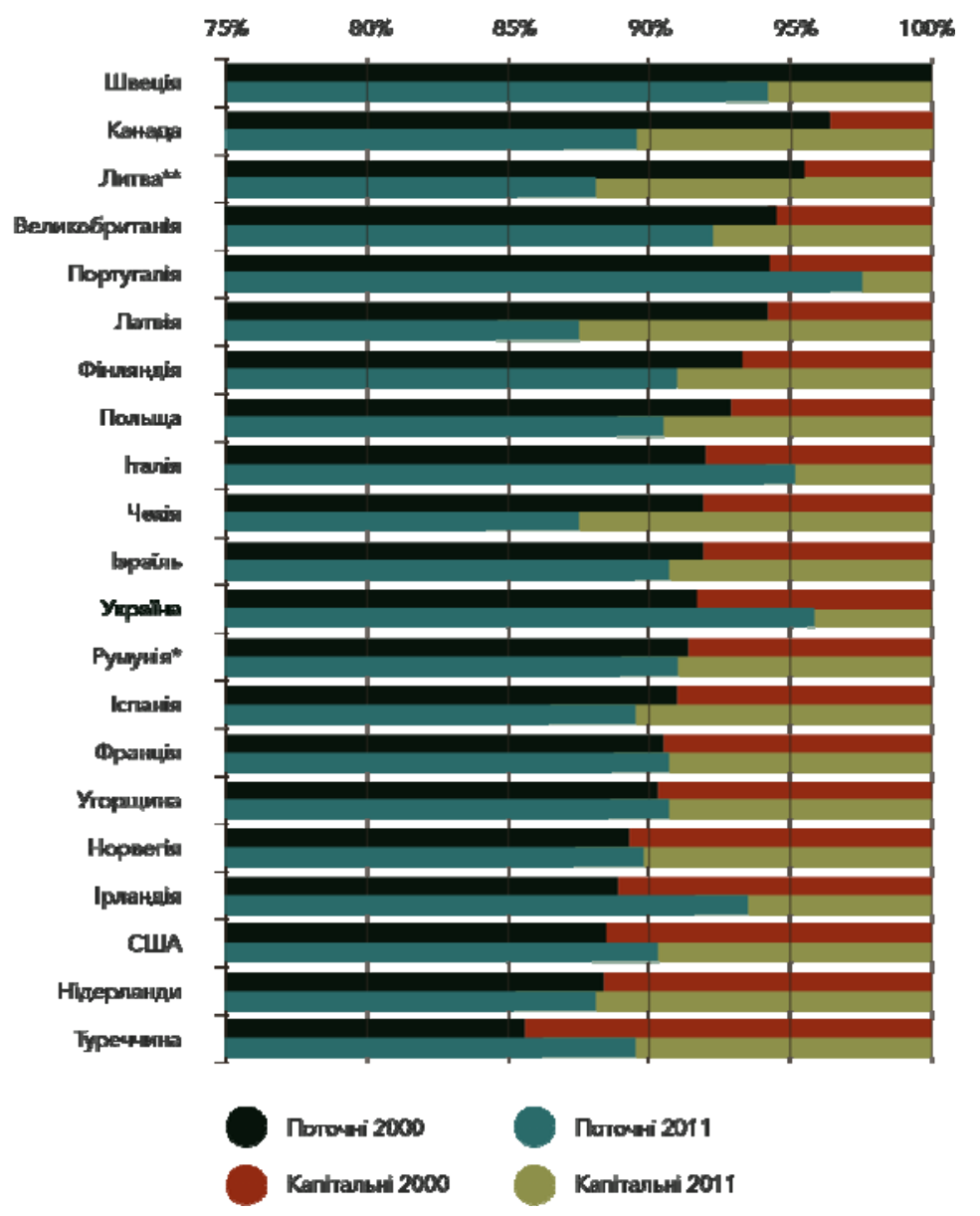

Рис. 2. Структура видатків у державних закладах освіти у \%, 2008-2011 pp.

(Джерело: Державна служба статистики, OECD

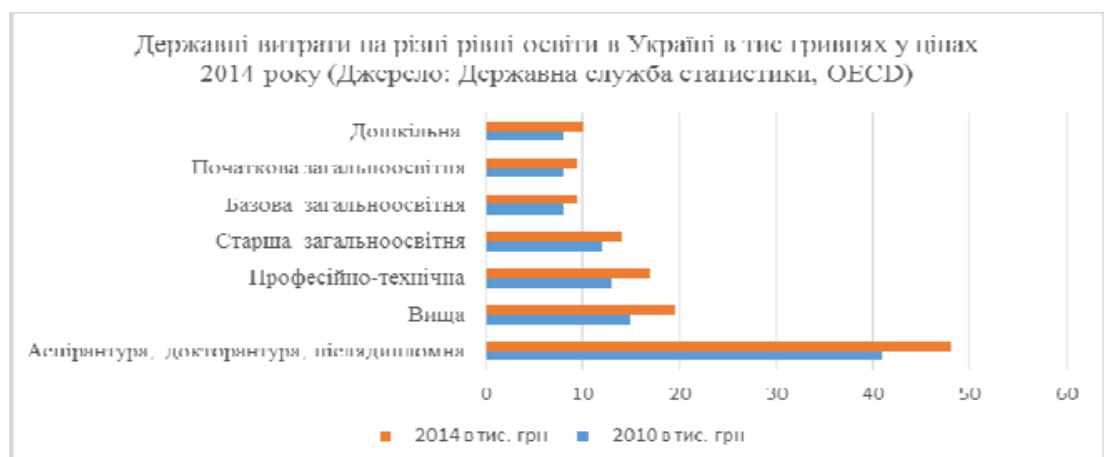

Рис. 3. Державні витрати на різні рівні освіти в Україні в тис гривнях у цінах 2014 року (Джерело: Державна служба статистики, OECD) 


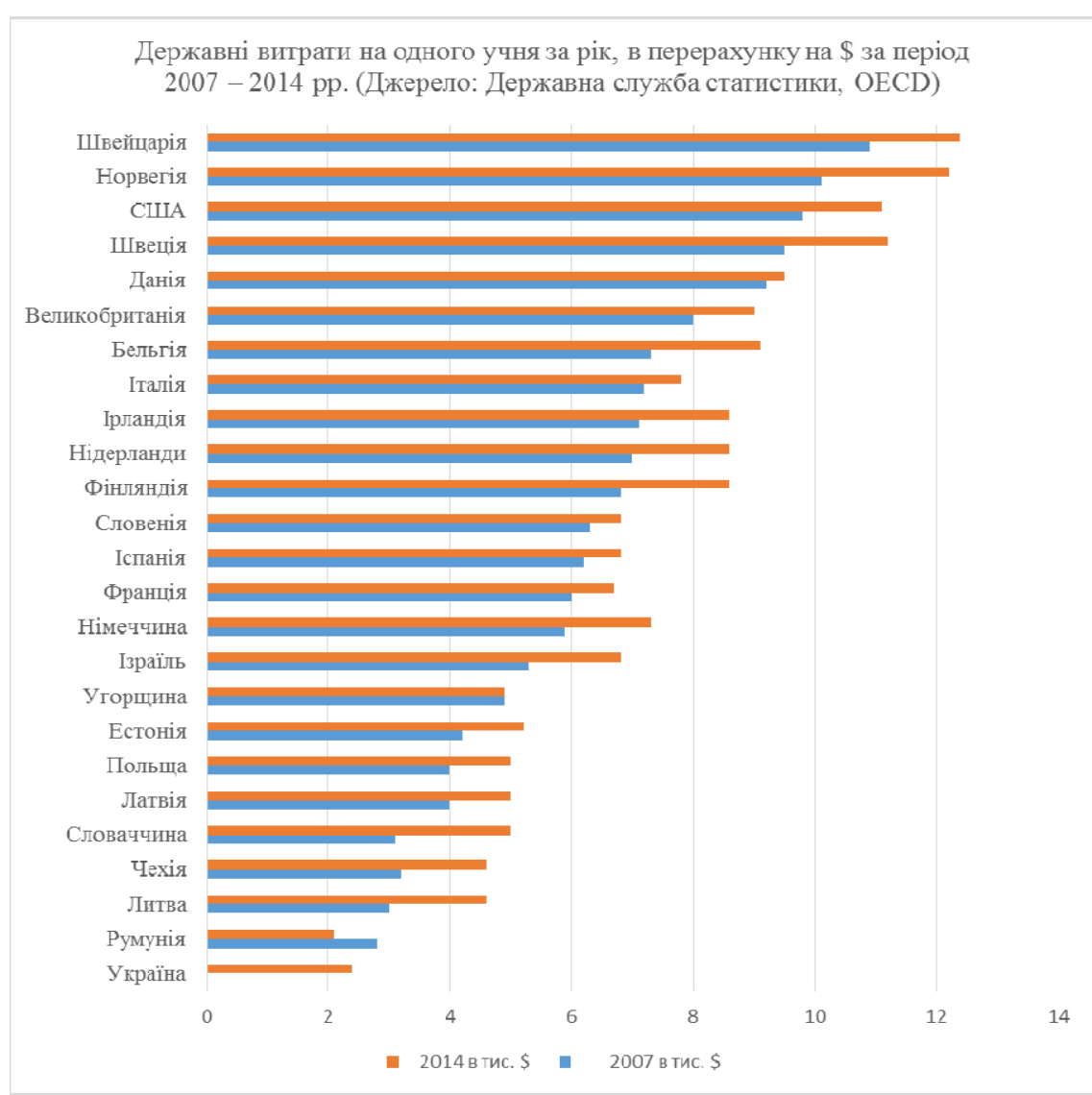

$a$

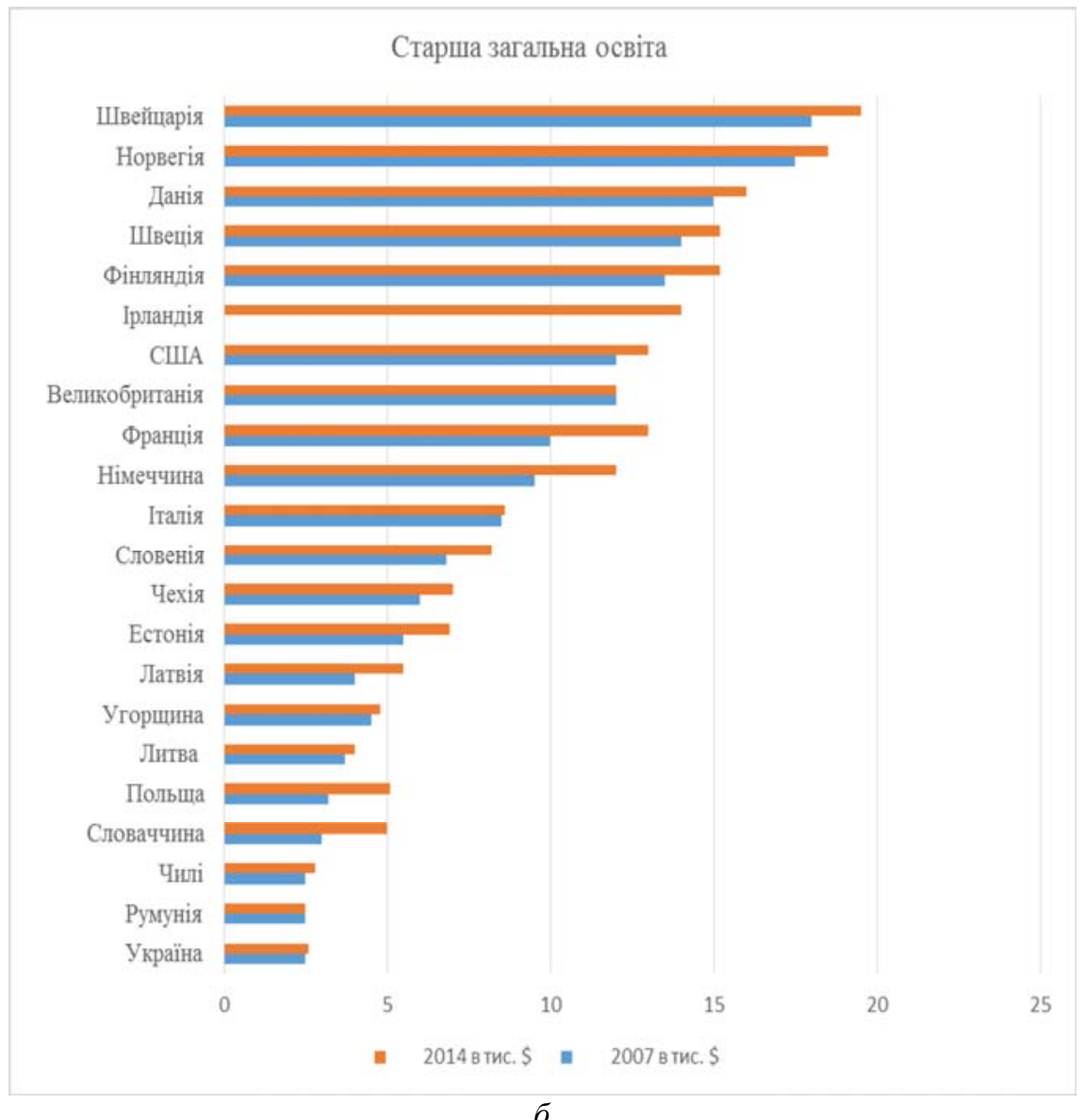

Рис. 4 Державняі витрати на одного учня за рік, в перерахунку на \$ за період 2007-2014 pp.: $a$ - молодша школа; б - старша школа (Джерело: Державна служба статистики, OECD) 
3 точки зору динаміки витрат в освіті також цікавий аналіз показників річної заробітної платні вчителів в Україні та в країнах Західної Свропи (без врахування надбавок) (рис. 5).

Пояснення: для країн СС взято річну заробітну плату вчителів базової (lowersecondary) школи за 2014 рік, які працюють повний робочий день (на повній ставці), включаючи податки, але без плати за додаткові робочі обов'язки та доплати за кваліфікацію, вислугу років тощо. Для України взято заробітну плату вчителів, які працюють на повну ставку згідно з Єдиною тарифною сіткою розрядів і коефіцієнтів з оплати праці працівників установ, закладів та організацій окремих галузей бюджетної сфери. Посада вчителя ЗНЗ з вищою освітою відповідає 9 тарифному розряду. Крім цього, враховано $20 \%$ надбавку за престижність вчительської праці, яку у 2014 р. отримували усі педагогічні працівники (курс євро до гривні - в перерахунку за 2014 рік).

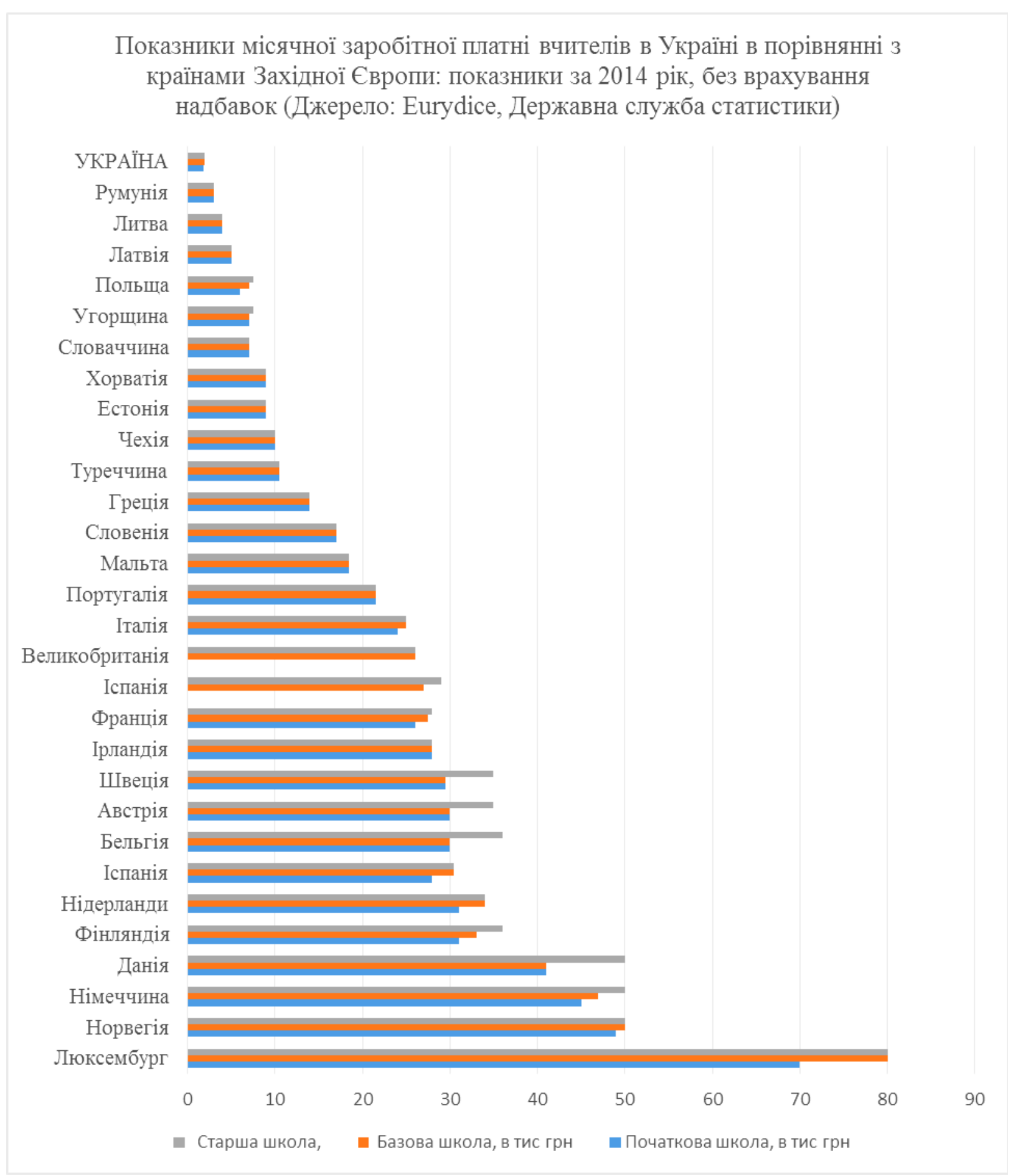

Рис. 5. Показники річної заробітної платні вчителів в Україні в порівнянні з країнами Західної Свропи: показники за 2014 рік, без врахування надбавок (Джерело: Eurydice, Державна служба статистики) 
На жаль, українські вчителі отримують у рази (чи навіть у десятки разів!) менше не лише за вчителів розвинених країн Західної Свропи, але й за своїх колег з країн постсоціалістичного табору (країн Балтики та Центральної Свропи). Базова вчительська зарплатня становить $28 \%$ відсотків ВВП на душу населення, тоді як у країнах Західної Свропи цей показник становить мінімум $80 \%$, подекуди сягаючи 135 \% (у Португалії) чи навіть 140 \% (у Німеччині). Втім, у сусідів України - Польщі, Чехії, Угорщини, Румунії, а також у країнах Балтики цей показник не надто високий (наприклад, у Латвії він становить всього 32 \%). Цікаво відзначити, що у переважній більшості західноєвропейських країн вчитель старшої школи отримує вищу зарплатню, ніж вчитель початкових класів, при однаковому навантаженні. У постсоціалістичних країнахвчителі шкіл усіх ступенів отримують однакову зарплатню.Рівень загальної освіти в країні відображеє міжнародний індикатор Індекс розвитку людського потенціалу (ІРЛП), який щорічно публікує ООН. в статистичному звіті. Остання опублікована версія звіту містить відомості за 2014 рік. Всі країни, що відносяться до категорії розвинених, повинні мати індекс більше 0,8 . На жаль, Україна має невисокий індекс - 0,74, що відносить іiі до країн з середнім рівнем розвитку освіти [9].

\section{5. Висновки}

Згідно 3 даними/показниками Міжнародних організацій (TIMSS, PIRLS, Eurydice), Державної служби статистики Міністерства освіти і науки України можна зробити наступні висновки щодо сучасного стану розвитку загальної освіти в Україні, а саме: видатки на освіту як частка від ВВП в Україні $є$ дуже високими в порівнянні з розвинутими країнами світу; особливістю фінансування освіти в Україні $є$ його розпорошеність, частка капітальних видатків на освіту в Україні досить низька; в Україні найменші витрати на одного учня серед усіх країн Західної Свропи; витрати на заробітну платню вчителям в Україні $є$ дуже низьким в порівнянні з країнами Центральної і Західної Свропи; в розвинутих країнах розподіляють значно більшу частку державних витрат на користь середньої та середньої професійної освіти, а в Україні - на вищу. Україна займає 81-е місце серед країн світу і відноситься до країн з середнім індексом розвитку людського потенціалу (відповідно невисокий рівень розвитку середньої освіти).

Проведений аналіз існуючого стану розвитку загальної освіти та джерел формування фінансових ресурсів освітніх установ в Україні уможливив визначити, на думку автора, пріоритетні напрями удосконалення системи фінансування загальної освіти, i, відповідно розробки та удосконалення системи критеріїв/показників прогнозування іiі розвитку, а саме:розробка системи показників контролю цільового використання державних і недержавних коштів; збір і розповсюдження інформаціі//показників щодо стану використання державних витрат на різних рівнях освіти, показників структури загальних витрат на 3СО; міжнародні консультації, моделювання та обговорення принципової нової схеми i механізму вдосконалення системи фінансування освіти в Україні та показників/критеріїв ії розвитку; регулювання оплати праці вчителів та розробка показників/критеріїв оцінювання соціального стану вчителів; удосконалення науково-методичного забезпечення освітнього процесу та створення системи критеріїв/показників рівня фундаментальних/прикладних досліджень в Україні.

\section{Література}

1. Законодавство України про освіту [Текст]: збір. законів. - К.: Парламент, 2010.

2. Даниленко, Л. І. Ефективність управління загальноосвітньою школою: соціально-педагогічний аспект [Текст]: монографія / Л. І. Даниленко, Н. М. Островерхова. - К.: Школяр, 1996. - 302 с.

3. Дмитренко, Г. А. Цільове управління: вимірювання результативності діяльності учнів і педагогів [Текст]: навч.-метод. посібник / Г. А. Дмитренко, В. В. Олійник, О. Л. Ануфрієва. - К.: УІПККО, 1996. - 84 с.

4. Клокар, Н. І. Інституаційний розвиток та професійний розвиток персоналу закладу післядипломної педагогічної освіти [Текст]: навч.-метод. комплекс / Н. І. Клокар. - К.: КОІПОПК, 2010. - 192 с.

5. Браже, Т. Г. Самодиагностика проффесиональной деятельности учителя. Диагностические и обучающие методики [Текст] / Т. Г. Браже, М. М. Заборщикова. - СПб., 1996. $-361 \mathrm{c}$.

6. Пікельна, В. С. Управління школою [Текст] / В. С. Пікельна. - Х.: Основа, 2004. - 112 с.

7. Дегтяр, А. О. Державне фінансування системи вищої освіти в Україні [Текст] / А. О. Дєгтяр, Я. В. Календжян // Держава та регіони. Серія: Державне управління. 2010. - № 4. - С. 153-156.

8. Кваліфікаційні вимоги до професійної діяльності педагогічних працівників. Аналітичний звіт за результатами дослідження 3 освітньої політики. Кн. 2 [Текст] / під ред. Г. В. Сльнікової. - Київ-Черкаси, 2010. - 96 с.

9. Когут, I. Бюджет освіти та науки 2016: що прийняли депутати [Електроний ресурс] / I. Когут, Є. Стадний // CEDOS. - 2015. - Режим доступу: http://www.cedos.org.ua/uk/ osvita/biudzhet-osvity-ta-nauky-2016-shcho-pryinialy-deputaty

10. Демчук, О. Благодійні фонди - запорука прозорого використання неурядових коштів у державних закладах освіти [Електронний ресурс] / О. Демчук // Громадянська Освіта. - 2005. - № 6. - Режим досту: http:// osvita.khpg.org/index.php?id=1123088405

\section{References} Parlament.

1. Zakonodavstvo Ukrai'ny pro osvitu (2010). Kyiv:

2. Danylenko, L. I., Ostroverhova, N. M. (1996). Efektyvnist' upravlinnja zagal'noosvitn'oju shkoloju: social'nopedagogichnyj aspekt. Kyiv: Shkoljar, 302.

3. Dmytrenko, G. A., Olijnyk, V. V., Anufrijeva, O. L. (1996). Cil'ove upravlinnja: vymirjuvannja rezul'tatyvnosti dijal'nosti uchniv i pedagogiv. Kyiv: UIPKKO, 84.

4. Klokar, N. I. (2010). Instytuacijnyj rozvytok ta profesijnyj rozvytok personalu zakladu pisljadyplomnoi' pedagogichnoi' osvity. Kyiv: KOIPOPK, 192.

5. Brazhe, T. G., Zaborshhikova, M. M. (1996). Samodiagnostika proffesional'noj dejatel'nosti uchitelja. Diagnosticheskie i obuchajushhie metodiki. Sankt-Peterburg, 361.

6. Pikel'na, V. S. (2004). Upravlinnja shkoloju. Kharkiv: Osnova, 112.

7. Djegtjar, A. O., Kalendzhjan, Ja. V. (2010). Derzhavne finansuvannja systemy vyshhoi' osvity v Ukrai'ni. Derzhava ta regiony. Serija: Derzhavne upravlinnja, 4, 153-156. 
8. Jel'nikova, G. V. (Ed.) (2010). Kvalifikacijni vymogy do profesijnoi' dijal'nosti pedagogichnyh pracivnykiv. Analitychnyj zvit za rezul'tatamy doslidzhennja z osvitn'oi' polityky. Kn. 2. Kyiv-Cherkasy, 96.

9. Kogut, I., Stadnyj, Je. (2015). Bjudzhet osvity ta nauky 2016: shho pryjnjaly deputaty. CEDOS. Available at: http://www.cedos.org.ua/uk/osvita/biudzhet-osvity-ta-nauky2016-shcho-pryinialy-deputaty

10. Demchuk, O. (2005). Blagodijni fondy - zaporuka prozorogo vykorystannja neurjadovyh koshtiv u derzhavnyh zakladah osvity. Gromadjans'ka Osvita, 6. Available at: http:// osvita.khpg.org/index.php?id=1123088405

Рекомендовано до публікачії д-р пед. наук, професор Островерхова Н. М. Дата надходження рукопису 06.09.2016

Климчук Ірина Олександрівна, кандидат педагогічних наук, старший науковий співробітник, Інститут педагогіки, Національна Академія педагогічних наук України, вул. Січових Стрільців, 52-А, м. Київ, Україна, 04053

E-mail: Klimchuk.irina@gmail.com

УДК 374.32

\section{RESEARCH GENDER SOCIALIZATION AS SOCIO-PEDAGOGICAL PROBLEM}

\section{(C) V. Syniakova}

Метою статті є дослідження поняття «гендерна сочіалізація», як соиіально педагогічної проблеми. Відповідно до мети проаналізовано поняття «соиіалізація» та визначено ї̈ феномени. Провідним агентом соичіалізації визнано родину, а важливою складовою соиіалізації- «гендерну соиіалізаціюю. У статті висвітлено сутнісні характеристики понять «стать» та «тендер», подане авторське визначення поняття «тендер» та розмежсовано поняття «гендерна» та «статеворольва» сочіалізачія

Ключові слова: гендерна сочіалізація, стать, гендер, механізми соціалізаџї, гендерна освіта, гендерне виховання

The purpose of the article is to present a study of the concept of "gender socialization" as a socio-pedagogical problem. According to the purpose of the article, we analyzed the notion of "socialization" and its phenomena. The leading agent of socialization is recognized as a family and an important part of socialization is "gender socialization." The article represents the main characteristics of the concepts of "sex" and "gender", the author's definition of the concept of "gender" and the difference between the concept of "gender" and "role-gender socialization". It was also studied the relationships between the concepts of "gender socialization", "gender training» and "gender education». Summing up the position expressed by, we proposed a formula to describe the process of gender socialization

Keywords: socialization, gender socialization, agents of socialization, mechanisms of socialization, gender, gender education

\section{Introduction}

In the course of one of its stages, the historical development of humanity naturally led to the emergence of a community of people which must act as a single entity. Thus, the complicated problem of overcoming the multivalency of the approaches to the subjective perception of the world arose and it was inevitable to develop a coherent view about it, i. e. the construction of a common vision for all. In the animal environment (kingdom), the problem of coordinating actions between private individuals is solved not only at the genetic level, but also at the level of the formation of a purely individual experience of interaction with other individuals.

People solve the problem of subjective separateness when they create common for all «environment concepts» using artificial external samples, such as signs (language, customs, traditions, etc.). By learning the system of generally accepted notions, ideas, and views, through a general activity and communication with other people, the «socialized subject» is included in the social environment of people of a certain culture, relatively acquires the human essence. In this connection, the problems of socialization never lose their relevance, they only change their perspective.

\section{Literature review}

The comprehension of the human socialization problem began long before the propagation of the relevant term. The question of how a person becomes a competent member of society has always been at the focus of philosophers, writers and authors of memoirs and in the last third of the XIX century it began to be intensively explored by sociologists and social psychologists. Currently, the concept of "socialization" is a central one in the different social sciences: philosophy, psychology, pedagogy, sociology, political science and others.

Since the term "socialization" is widely used by researchers of the various scientific branches, we believe 